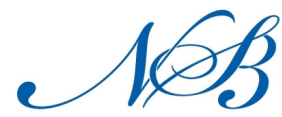

Notulae Scientia Biologicae

\title{
MtDNA Barcode Identification of Finfish Larvae from Vellar Estuary, Tamilnadu, India
}

\author{
Ramakrishnan THIRUMARAISELVI, Sourin DAS, \\ Vellaichamy RAMANADEVI, Muthusamy THANGARAJ*
}

Annamalai University, Centre of Advanced Study in Marine Biology, 608502 Parangipettai, Tamil Nadu India; coralholder@yahoo.com (*corresponding author)

\begin{abstract}
Planktonic larvae were captured in the shallow Vellar estuary, Tamilnadu, India, during January to June 2013 using zooplankton net. Larvae were identified to the species level by comparison with Genbank data base using MtDNA sequence data. Further analysis showed that there is no sequence variation within-species, whereas between-species variation was more than $25 \%$, supporting the suitability for species identification. The highest genetic distance was observed between A. nigropunctatus and $M$. cephalus (0.434) and the lowest genetic distance was observed between T. jarbua and S. commersoni (0.256). Given the current worldwide interest in DNA barcoding and species identification using MtDNA gene marker (CO1), it was confirmed the efficacy of the Fish-F1 and -R1 primer set, which gave the possibility for identification of finfish larvae at species level.
\end{abstract}

Keywords: cytochrome oxydase I, genetic distance, ichthyoplankton, mitochondria

\section{Introduction}

In the early life history of fishes, many species share the same morphology and their morphometric measurements are often duplicated (Victor et al., 2009). Traditionally, the larval fish has always been identified by morphological characters, such as the body shape, pigmentation, meristic count and measurements. However, these characters are not enough to identify each species, especially those are rare and cryptic (Matarese et al., 2011). The morphology of the same species can change quickly and significantly during its development from preflexion larvae to postflexion and to the pre-juvenile stage, when the fish settles down. Thus, the same species at different developmental stages may be identified as several different species when using just morphological characters (Ko et al., 2013). The basic characters normally employed for the identification of finfish larvae belonging to various families are the shape of the body, shape of the gut, position of anal opening, type of alimentary canal, arrangement of muscle fibres, number of myotomes, origin and position of paired and unpaired fins besides changing pattern of pigmentation etc. (Sundaramanickam, 2004).

Marine fish larval identification would be a very difficult task among the huge species diversity of teleost fishes if the research is merely based on limited morphological observation of field sampling larval fish species (Yamaguchi $e t$ al., 2000). Shao et al. (2002) has pointed out that only molecular identification can give guarantee identification of the fish eggs to the species level and this conclusion can be applied to larval fish identification too. The application of DNA barcoding to the larval fish identification has become so popular in recent years (Pegg et al., 2006). DNA barcoding is a concept in which a short nucleotide sequence of mitochondrial genome will act as a DNA barcode for species identification of eukaryotes, in particular animals, and it is proven to be a rapid tool for precise identification of biological specimens. DNA barcoding works under the principle that inter species variations are greater than the intra species variations, allowing one to distinguish the species using nucleotide sequences. Cytochrome c oxidase subunit I gene (CO1) have been accepted as a universal barcode to delineate animal life of this planet. DNA barcode technique could be used as a rapid tool to survey many uncertain species, species composition and cryptic species of adults in a study area (Spies, 2006) as well as morphologically similar species (Ward et al., 2008). DNA barcoding can speed the discovery of new species, as large sequence differences in animal MtDNA generally give species status (Krishna et al., 2012).

Vellar estuary is in the southeast coast of India $\left(11^{\circ} 30^{\prime} \mathrm{N}\right.$; $79^{\circ} 46^{\prime} \mathrm{E}$ ) and harbours many euryhaline fishes, many of them commercially important. It joins to Bay of Bengal at Parangipettai and is said to be a 'true estuary' as there is no complete closure of the mouth. This estuary has been demarcated into marine, gradient, tidal and freshwater zones, based on salinity characteristics. It is subjected to semi-diural tides with maximum tidal amplitude of about $1 \mathrm{~m}$. The average depth ranges between 2.3 and $5.0 \mathrm{~m}$. Influence of the neritic water with the estuarine environment promotes a perfect exchange of both biotic and abiotic components and the tidal influence extends over a distance of $16 \mathrm{~km}$ upstream of the estuary. The estuary extends over an area of 262 ha and 600 meters wide at its junction with the sea. Mangroves have 
been developed over an area of 10 ha along the northern bank of the estuary in the estuarine zone. A recent study reported that that there are 95 species of finfishes available in this estuary (Murugan et al., 2014). Never the less, the larval biodiversity data is sparse in this estuary. The objective of this study is to identify some dominant fish larvae in Vellar estuary upto species level using CO1 gene and find the phylogenetic relationship among them.

\section{Materials and methods}

\section{Larvae collection and identification}

Fish larvae were collected under the mangrove areas of Vellar estuary during tide periods early in the morning and in the evening, with the help of zooplankton net with a mesh size of $158 \mu \mathrm{m}$. The collected larvae were divided into four groups as per the initial morphometric characters, such as body shape, length and width and transferred into $2 \mathrm{ml}$ eppendorf tubes containing 95\% ethanol. Photographs were taken by using a microscope mounted with digital camera. Morphometric identification was done by following the report of Ramaiyan et al. (2005). The basic characters used for the identification were: size of the body, shape of the larvae, nature of muscle fibers, number of myotomes, alimentary canal, position of the vent, origin and location of paired and unpaired fins and changing pattern of pigmentation.

\section{DNA isolation, PCR and COI gene sequencing}

DNA was isolated from the individual fish larvae by the standardized salting-out procedure (Sambrook et al., 1989). Quantity and quality of the extracted DNA was checked in UV spectrophotometer, $0.8 \%$ agarose gel electrophoresis respectively. The CO1 gene was amplified in a $50 \mu \mathrm{L}$ of PCR mix containing $5 \mu \mathrm{L}$ of $10 \mathrm{X}$ Taq polymerase buffer, $2 \mu \mathrm{L}$ of $\mathrm{MgCl}_{2}(50 \mathrm{mM}), 0.25 \mu \mathrm{L}$ of each dNTP $(0.05 \mathrm{mM}), 0.5 \mu \mathrm{L}$ of each primer $(0.01 \mathrm{mM}), 0.6 \mathrm{U}$ of Taq polymerase and $2 \mu \mathrm{L}$ of genomic DNA. The universal primers for CO1 gene, FishF1-5' TCAACCAACCACAAAGACATTGGCAC$3^{\prime}$ and FishR1-5' TAGACTTCTGGGTGGCCAAA GAATCA-3' (Ward et al., 2005) were used. The thermal regime consisted of an initial denaturation step for $3 \mathrm{~min}$ at $95^{\circ} \mathrm{C}$ followed by 35 cycles of $30 \mathrm{~S}$ at $94^{\circ} \mathrm{C}, 30 \mathrm{~S}$ at $45^{\circ} \mathrm{C}$ and $1 \mathrm{~min}$ at $72^{\circ} \mathrm{C}$, followed by final extension for $10 \mathrm{~min}$ at $72{ }^{\circ} \mathrm{C}$. The PCR products were visualized on $1.5 \%$ agarose gels and the most intense products were cleaned up and sequenced by a commercial sequencing facility.

\section{Sequence analysis}

The CO1 gene partial sequences of the selected individuals were unambiguously edited, aligned using CLUSTAL-W in BioEdit and checked manually. All the sequences were confirmed by similarity index by the NCBI's BLAST program. Based on the higher percentage similarity and query coverage against the reference species, the species were confirmed. All the sequences were submitted to the NCBI's Genbank. Genetic distance within species and between species were determined by Kimura 2-Parameter method (Kimura, 1980) using the software program MEGA 3.1 (Kumar et al., 2004). The neighbour-joining (NJ) tree for CO1 was constructed and to verify the robustness of the internal nodes, bootstrap analysis was carried out using 1,000 pseudo-replications.

\section{Results and discussions}

\section{Molecular identification}

Totally, 456 larval samples were collected from the intertidal region of Vellar estuary. Among these 456 larvae, four morphotypes were segregated based on the morphological characters and proceeded for molecular identification to confirm to species level. The four morphotype larval CO1 gene was successfully amplified and sequenced. PCR amplified CO1 gene showed $650 \mathrm{bp}$ in length and partial at both ends after editing. All the sequences showed first frame and no internal stop codons were observed. In BLAST, all the sequences showed $>99 \%$ similarity with CO1 gene of specific species in the NCBI nucleotide database. Based on the BLAST results, the morphotype 1 was identified as Mugil cephalus, morphotype 2 was identified as Scomberomorus commersoni, morphotype 3 was identified as Arothron nigropunctatus and morphotype 4 was identified as Terapon jarbua. The average percentage of base composition of the CO1 gene fragment in four fish species was as follows: $M$. cephalus A: $24.5, \mathrm{~T}: 31.0$, G: 17.5 , C: $27.0 \%$; S. commersoni A: 23.0, T: 29.5, G: 18.0, C: $29.5 \%$ and $A$. nigropunctatus A: 23.5, T: 26.5, G: 19.0, C: $31.0 \%$; $T$. jarbua A: 22.5, T: 28.0, G: 18.0, C: 31.5\%. The high AT content (55.05\%) was observed in Mugil cephalus (Fig. 1).

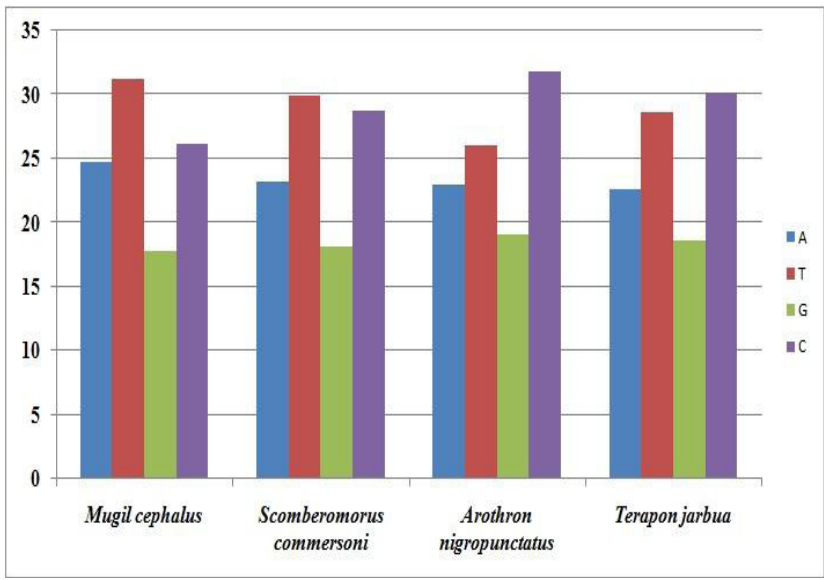

Fig. 1. Nucleotide percentage compositions of $\mathrm{CO} 1$ gene in the four fish species

\section{Genetic distance}

The genetic distances between the four species of fish larvae are given in Table 1 . The highest genetic distance was observed between $A$. nigropunctatus and $M$. cephalus (0.434) and the lowest genetic distance was observed between $T$. jarbua and $S$. commersoni (0.256). The overall mean genetic distance was 0.306 based on the $\mathrm{CO} 1$ gene sequence.

Table 1. K2P genetic distance within species (bold) and between species among the four fish larvae based on $\mathrm{CO} 1$ sequence data

\begin{tabular}{|c|c|c|c|c|}
\hline Species & Mugilcephalus & $\begin{array}{c}\text { Scomberomorus } \\
\text { commersoni }\end{array}$ & $\begin{array}{c}\text { Arothron } \\
\text { nigropunctatus }\end{array}$ & Teraponjarbua \\
\hline Mugilcephalus & 0.000 & & & \\
\hline $\begin{array}{c}\text { Scomberomorus } \\
\text { commersoni }\end{array}$ & 0.346 & 0.000 & & \\
\hline $\begin{array}{c}\text { Arothron } \\
\text { nigropunctatus }\end{array}$ & 0.434 & 0.340 & 0.000 & \\
\hline Terapon jarbua & 0.411 & 0.256 & 0.343 & 0.000 \\
\hline Overall mean & 0.306 & & & \\
\hline
\end{tabular}


18

\section{Phylogentic analysis}

In the dendogram analysis, individuals of the four species clustered into two major clades (Fig. 2). The first major clade consists of Arothron nigropunctatus, Terapon jarbua and Scomberomorus commersoni. From the dendogram it is ascertain that the fish genus is genetically homogenous. The second clade consists of $T$. jarbua. This phylogenetic construction using neighbour joining method shows the two clear branches without any change. All the species possess better node stability with good bootstrap values (100) for branch support.

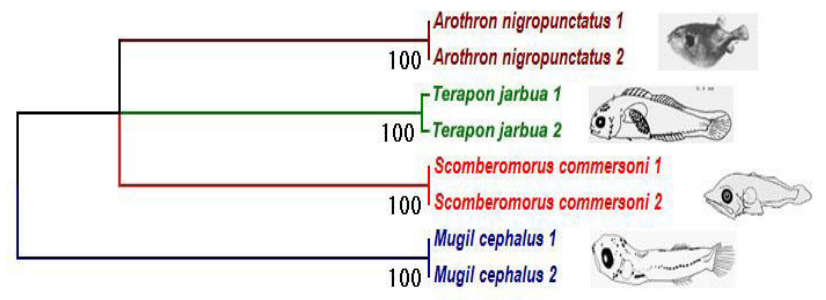

$\begin{array}{lllll}0.15 & 0.10 & 0.05 & 0.00 & \text { K2P Distance }\end{array}$

Fig. 2. Phylogenetic relationship of Mugil cephalus, Scomberomorus commersoni, Arothron nigropunctatus, Terapon jarbua from Vellar estuary

India is rich in diversity, not withstanding fish diversity and all the species occurring in the Indian waters need to be barcoded. Even so, only few efforts have been made for the protection of brackish water fishes, so in this view to extending this effort to Indian biodiversity, the present study was undertaken to barcode fish larvae in mangrove swamp of Vellar estuarine region. Recently, Lakra et al. (2011) were barcoded 115 species (belonging to 37 families and 79 genera) of marine finfishes that occurre in Indian waters. CO1 sequences of Terapon jarbua, Scomberomorus commersoni, Arothron nigropunctatus and Mugil cephalus larvae of this study showed close relationship with those of the respective species collected by Lakra et al. (2011) from the Indian waters. The molecular phylogenetic clustering (Fig. 2) also reveal the same topology for clustering closely related species as per Lakra et al. (2011). The average percentage of base composition of the $\mathrm{CO} 1$ gene fragment in fish larvae is also in agreements with the earlier study (Lakra et al., 2011). Where the average nucleotide composition of Scombrids was A: 23.20; T: 29.30, G: 18.90 ; C: $28.60 \%$, whereas in this study, for $S$. commersoni A: 23.0, T: 29.5, G: 18.0, C: $29.5 \%$. were noted. However, Jamandre et al. (2014) recently showed that in $M$. cephalus the control region was AT rich and poor in G content. This result also supports the present study results for M. cephalus A: 24.5, T: 31.0, G: 17.5, C: $27.0 \%$. For $A$. nigropunctatus the following data were scored: A: 23.5; T: 26.5; G: 19.0, C: 31.0\%, whereas similar observations were made by Badhe and Nandanpawar (2013). In T. jarbua studied, A: 22.5, T: 28.0, G: 18.0, C: $31.5 \%$ were recorded. Khan et al. (2010) has shown the same result in the average nucleotide frequencies of T. jarbua.

The usage of K2P genetic distance revealed that within the species, genetic variation is low compared to the one among the species. The highest genetic distance was observed between $A$. nigropunctatus and $M$. cephalus (0.434), followed by $T$. jarbua and $M$. cephalus (0.411) and the lowest genetic distance was observed between $T$. jarbua and $S$. commersoni (0.256). Similar observations were observed in various studies, which show that the genetic distance within the genus is lesser than between the genus (Blaxter and Floyd 2003; Borda and Siddall, 2004; Hebert et al., 2003). Thus, the genetic distances keep increasing when the sequence of fishes belongs to the different genera or families and this proves once again the stringency of barcode region of $\mathrm{CO} 1$ gene in species identification.

\section{Conclusions}

It is clearly revealed that larval fish identification using traditional morphological characters should be more conservative and able to identify only to the family or genus level, and not to the species level. CO1 barcodes are essential to verify the species identification of fish larvae, especially of morphologically similar species. This study of molecular identification discriminate fish larvae from Vellar estuary as Terapon jarbua, Scomberomorus commersoni, Arothron nigropunctatus and Mugil cephalus. Although barcoding remains one of the best methods to confirm species identification, molecular identification of larval fishes still has some deficiencies and bottlenecks. This can be overcome by use additional markers of mitochondrial and nuclear origin which should be more conserved in nature.

\section{Acknowledgements}

We thank Department of Biotechnology, Government of India, New Delhi, for financial assistance in the form of RGYI (BT/PR6419/GBD/27/434/2012). We also thank The Director, CAS in Marine Biology and The Authorities of Annamalai University for facilities and encouragement.

\section{References}

Badhe MR, Nandanpawar PC (2013). Molecular characterization as a significant tool for identification of Indian puffer fishes. J Cell Tissue Res 13(2):3611-3617.

Blaxter M, Floyed R (2003). Molecular taxonomics for biodiversity surveys; Already a reality. Trends Ecol Evol 18:268-269.

Borda E, Siddall ME (2004). Arhynchobdellida (Annelida: Oligochaeta: Hirudinida): Phylogenetic relationships and evolution. Mol Phylogenet Evol 30:213-225.

Hebert PDN, Cywinska A, Ball SL, Ward JR (2003). Biological identifications through DNA barcodes. Proc R Soc Biol Sci Ser B 270:313-321.

Jamandre BW, Durand JD, Tzeng WN (2014). High sequence variations in mitochondrial DNA control region among worldwide populations of flathead mullet Mugil cephalus. Int J Zoo 1-9.

Khan AS, Lyla PS, Akbar Jhon B, Prasanna Kumar C, Murugan S, Jalal KCA (2010). DNA Barcoding of Stolephorus indicus, Stolephorus commersonii and Terapon jarbua of Parangipettai coastal waters. Biotechnology $9(3): 373-377$. 
Kimura MA (1980). Simple method for estimating rate of base substitutions through comparative studies of nucleotide sequences. J Mol Evol 16:111-120.

Ko HL, Wang YT, Chiu TS, Lee MA, Leu MY, Chang KZ, Chen WY, Shao KT (2013). Evaluating the accuracy of morphological identification of larval fishes by appling DNA barcoding. Plose One 8(1):e53451.

Krishna PV, Madhusudhana Rao K, Srinivasa Rao D (2012). Identification of selected estuarine fishes by DNA barcoding from river Krishna region, Andhra Pradesh, India. Int J R Pharm Bio Sci 3(3):1044-1049.

Kumar S, Tamura K, Nei M (2004). MEGA3: Integrated software for Molecular Evolutionary Genetics Analysis and sequence alignment. Brief Bio Info 5:150-163.

Lakra WS, Verma MS, Goswami M, Lal KK, Mohindra V, Punia P, Gopalakrishnan A, Singh KV, Ward RD, Hebert PDN (2011). DNA barcoding Indian marine fishes. Mol Ecol Res 11:60-71.

Matarese AC, Spies IB, Busby MS, Orr JW (2011). Early larvae of Zesticelus profundorum (family: Cottidae) identified using DNA barcoding. Ichthyol Res 58:170-174.

Murugan S, Ajmal Khan S, Lyla PS, Manokaran S, Raja S, Akbar John B (2014). Spatial and temporal variability in fish diversity of Vellar estuary (Southeast Coast of India). Annu Res Rev Biol 4(13):2147-2162.

Pegg GG, Sinclair B, Briskey L, Aspden WJ (2006). MtDNA barcode identification of fish larvae in the southern Great Barrier Reef, Australia. Sci Mar 10:7-12.

Ramiyan V, Balasubramanian T, Kannaupandi T, Khan SA, Rajagopal S, Lyla PS (2005). Monograph on eggs and larvae of fin and shell fish collected from Parangipettai and adjacent waters along the Southeast coast of India. Annamalai University, Dept of Ocean Development. Govt. of India, $109 \mathrm{p}$.
Sambrook J, Fritsch EF, Maniatis cloning: A laboratory Manual. II edn. Cold Spring Harbour Laboratory. Press, Cold Spring Harbour, N.Y.

Shao KT, Chen KC, Wu JH (2002). Identification of marine fish eggs in Taiwan using light microscope, scanning electron microscope and mtDNA sequencing. Mar Freshw Res 53:355-365.

Spies IB, Gaichas S, Stevenson DE, Orr JW, Canino MF (2006). DNA-based identification of Alaska skates (Amblyraja, Bathyraja and Raja: Rajidae) using cytochrome c oxidase subunit I (COI) variation. J Fish Biol 69:283292.

Sundaramanickam A (2004). Distribution of finfish larvae in relation to hydrographical parameters in parangipettai coast and adjacent water (South East Cost of India). PhD. Thesis, Annamalai University, India, $174 \mathrm{p}$.

Victor BC, Hanner R, Shivji M, Hyde J, Caldow C (2009). Identification of the larval and juvenile stages of the cubera snapper, Lutjanus cyanopterus, using DNA barcoding. Zoo Taxa 2215:24-36.

Ward RD, Costa FO, Holmes BH, Steinke D (2008). DNA barcoding of shared fish species from the North Atlantic and Australia: minimal divergence for most taxa, but Zeus faber and Lepidopus caudatus each probably constitute two species. Aquatic Biology 3:71-78.

Ward RD, Zemlac TC, Innes BH, Last PR, Hebert PDN (2005). DNA barcoding Australia's fish species. Philosophical Transact Royal Soc B 360:1847-1857.

Yamaguchi M, Miya M, Okiyama M (2000). Molecular phylogeny and larval morphological diversity of the lanternfish genus Hygophum (Teleostei: Myctophidae). Mol Phylogenet Evol 15(1):103-114. 